Portland State University

PDXScholar

1978

\title{
Small mammal dissemination of dwarf mistletoe seeds
}

Daniel Eugene Lemons

Portland State University

Follow this and additional works at: https://pdxscholar.library.pdx.edu/open_access_etds

Part of the Biology Commons, and the Plant Sciences Commons Let us know how access to this document benefits you.

\section{Recommended Citation}

Lemons, Daniel Eugene, "Small mammal dissemination of dwarf mistletoe seeds" (1978). Dissertations and Theses. Paper 2845.

https://doi.org/10.15760/etd.2839

This Thesis is brought to you for free and open access. It has been accepted for inclusion in Dissertations and Theses by an authorized administrator of PDXScholar. Please contact us if we can make this document more accessible: pdxscholar@pdx.edu. 
AN ABSTRACT OF THE THESIS OF Daniel Eugene Lemons for the Master of Arts in Biology presented February 24, 1978.

Title: Small Mammal Dissemination of Dwarf Mistletoe Seeds. APPROVED BY MEMBERS OF THE THESIS CONMITMEE:

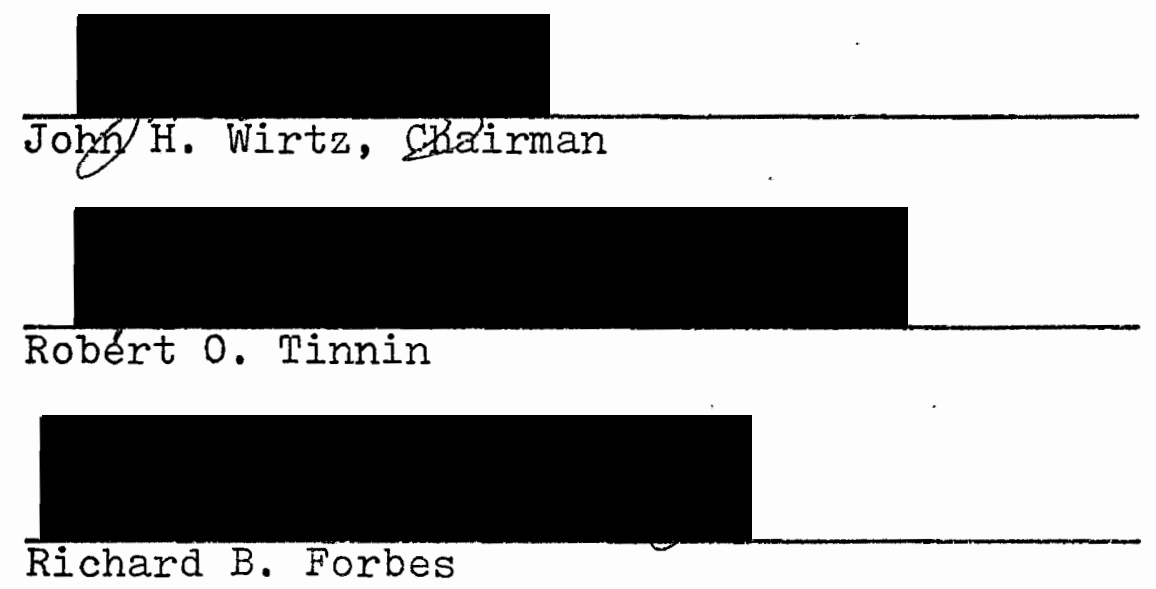

Dwarf mistletoes (Arceuthobium spp.) have been thought to spread mainly by means of explosive fruits that expel seeds under hydrostatic pressure to distances up to $130 \mathrm{ft}$. Recently birds and mammals have been considered possible agents in long distance dissemination of the seeds. This study investigates the role that small mammals, especially the red squirrel (Tamiasciurus hudsonicus), may play in seed dispersal.

The study was conducted in the Malheur National Forest on Graham Creek near Prairie City, Oregon. Mistletoe species present were A. campylopodum, A. douglasil, A. 
laricis and $\underline{A}$. americanum, and primary host species of each were Pinus ponderosa, Pseudostuga menziesii, Laricis occidentalis and Pinus contorta respectively. Two separate areas, $A$ and $B$, were studied and characterized for species composition and extent of mistletoe infection. A study area in area $B$ was established for observing behavior and movement of red squirrels. Squirrels were trapped and shot in each area when the seeds began to erupt.

The two stands varied slightly in species composition and drastically in their degree of infection. No seeds were found on trapped or shot squirrels in area $B$ where infection was low. $50 \%$ of the squirrels trapped or shot in area $A$ carried seeds on their fur. It appears that squirrels do carry mistletoe seeds over distances up to $150 \mathrm{~m}$. If their territory is in a stand that exceeds a threshold level of infection. The number of seeds carried per year can be predicted. It is doubtful whether a significant number of infections result from squirrel dispersal of seeds since most seeds carried on the fur are probably groomed off in an uninfectable part of the host tree. 
SMALI MAMMAI DISSEMINATION

OF DWARF MISTIETOE SEEDS

by

DANIEI EUGENE LEMONS

A thesis submitted in partial fulfillment of the requirements for the degree of

\section{MASTER OF SCIENCE \\ in \\ BIOLOGY}

Portland State University

1978 
TO THE OFFICE OF GRADUATE STUDIES AND RESEARCH:

The members of the Committee approve the thesis of Daniel Eugene Lemons presented February 24, 1978.
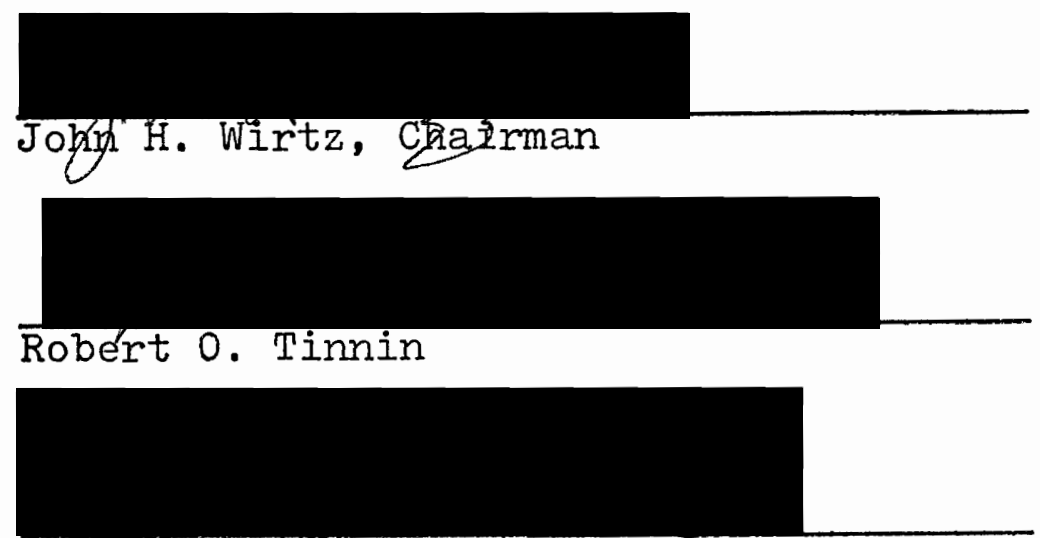

Richard B. Forbes

APPROVED:
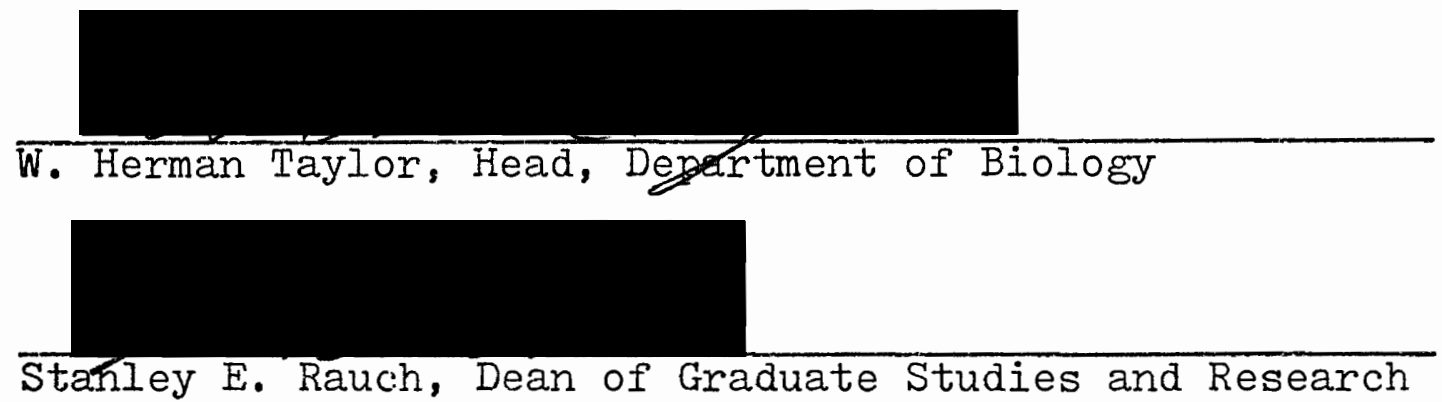


\section{ACKNOWLEDGENENTS}

I would like to thank Dr. John H. Wirtz who served as my advisor during the planning and execution of this research, Dr. Robert 0 . Tinnin who gave important advice, criticism and support, and Dr. Richard B. Forbes who loaned lab space and gave counsel during this project. Deserving special thanks for her long and constant support throughout this project is Mary Smucker who helped lay out transects, type manuscripts and proof final copy. I finally want to thank Judy Stutzman for the patience with which she did an excellent job of typing. 
TABLE OF CONTENTS

PAGE

ACKNOWLEDGEMENTS $\ldots \ldots \ldots \ldots \ldots \ldots \ldots \ldots \ldots \ldots \ldots \ldots \ldots \ldots \ldots \ldots$

IIST OF TABLES $\ldots \ldots \ldots \ldots \ldots \ldots \ldots \ldots \ldots \ldots \ldots \ldots \ldots \ldots \ldots$

IIST OF FIGURES $\ldots \ldots \ldots \ldots \ldots \ldots \ldots \ldots \ldots \ldots \ldots \ldots \ldots \ldots \ldots \ldots$

CHAPTER

I INTRODUCTION $\ldots \ldots \ldots \ldots \ldots \ldots \ldots \ldots \ldots \ldots$

General Description .............. 1

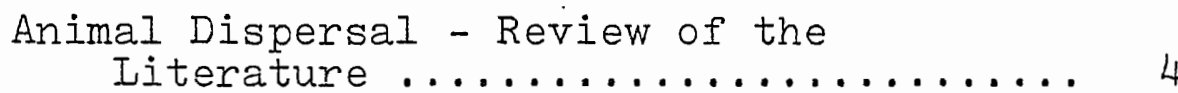

Purpose of Study ................ 5

I I METHODS AND MATERIALS .............. 6

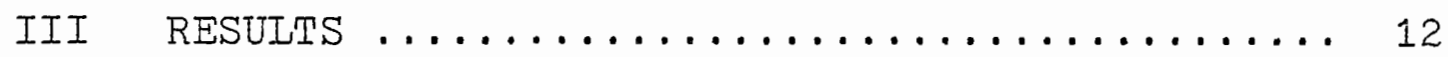

Behavior ................... 12

Stand Evaluation ................. 14

Trapping and Shooting ............ 17

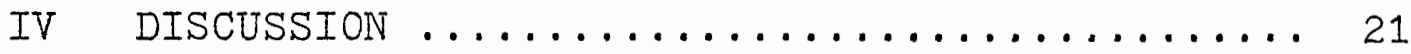

Potential for Intercepting

Mistletoe Seeds ............... 21

Avoidance of Mistletoe

Infection Index

Prediction of Yearly Seed

Encounter

Distance of Seed Dispersal ........... 27

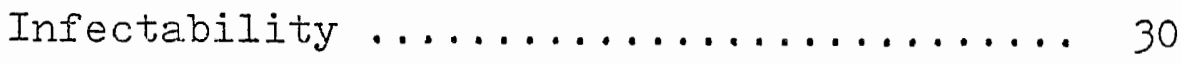

Role of Other Mammals ............. 31 
CHAPTER PAGE

y CONCLUSION AND RECONIENDATIONS ......... 33

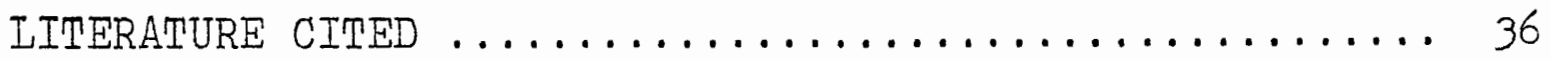




\section{IIST OF TABIES}

TABLE

PAGE

I Trap Site Evaluation Results . . . . . . 15

II Trapping and Shooting Results . . . . . . 19 


\section{LIST OF FIGURES}

FIGURE

PAGE

1 Mistletoe Iife Cycle . . . . . . . . . 3

2 Trap Site Evaluation Sampling Pattern . . . 9

3 Squirrel Activity Periods . . . . . . . 13

4 Infection Indices of Area A and Area B . . . 16

5 Trapping and Shooting Results . . . . . 20

6 Proposed Relation of Encounter Probabilities

to Infection Indices . . . . . . . 25

7 Possible Route of Infection Seed

Advancement . . . . . . . . 29 


\section{INTRODUCTION}

\section{General Description}

Dwarf mistletoes (Arceuthobium sp.) are a group of flowering plants parasitic on conifers. A genus of the family Viscaceae, Arceuthobium, is found in Africa, Europe, Asia, North and Central America and the West Indies. Seven species occur in Dregon.

Arceuthobium uses water, nutrients and minerals from the host tree, and it reduces seed production and wood quality and enhances fungal infection of the host tree (Hawksworth and Wiens, 1972). Meyers and Hawksworth (1972) noted that timber yields of infected stands were one-fourth to one-half that of healthy stands. It is estimated that approximately $150 \times 10^{6}$ cubic feet of timber are lost annually to mistletoe in Oregon and Washington (Stewart and Shea, 1970).

Arceuthobium is not dependent on avian dispersal which is a frequent mechanism of spread in other mistletoe genera (Kuijt, 1969; Gill and Hawksworth, 1961). Dwarf mistletoes have explosive fruits that fire under hydrostatic pressure. Seeds may discharge at speeds up to $50 \mathrm{mph}$ and may travel up to 130 feet horizontally in the airection of prevailing winds (Roth, 1953), though the average distance traveled is a few feet (Parmeter and Scharpf, 1972; Hudler, 1976). 
Seeds are coated with viscin that makes them extremely sticky so they readily adhere to twigs or needles they strike.

The generalized Iife cycle of Arceuthobium is shown in Figure 1. After seeds have germinated and the penetration peg has entered the host tissue, the first visible sign of infection is a swelling of host tissue in the area of the infection. After three to four years, aerial shoots emerge and after four to five years flowering occurs.

One of the major responses of the host tree to mistletoe infection is the proliferation of branches around the infected area, eventually forming a dense clump of growth called a witch's broom. Many investigators suspect that the broom preempts the uninfected portions of the tree (especially adjacent to the infection), and consequently healthy parts eventually die.

Numerous mammals, including deer, elk and porcupines, feed on dwarf mistletoe aerial shoots. Chipmunks are reported to eat the seeds (Broadbrooks, 1958), and in the spring porcupines and squirrels eat the living bark tissues of the host trees around the swellings caused by infection (Baranyay, 1968). Squirrels and birds also nest in mistletoe brooms apparently because the brooms provide excellent cover. Some Indian tribes have used the aerial shoots medicinally. 


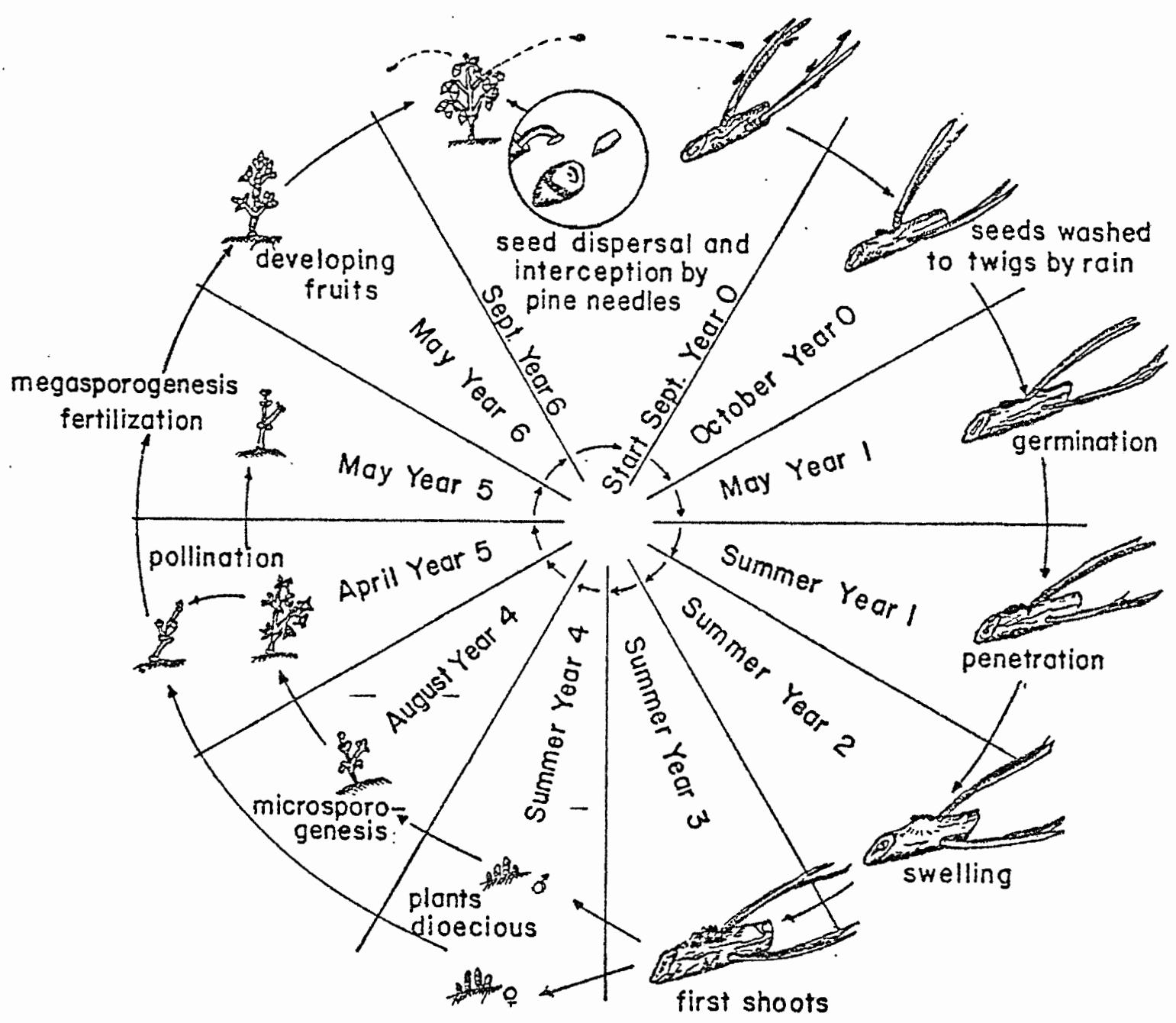

Figure 1. Mistletoe life cycle. 
Animal Dispersal - Review of The Literature

It has generally been held that dwarf mistletoe is not dependent on animals for dispersal (Kuijt, 1969; Hawksworth and Wiens, 1972), although Ridley (1930) felt that the parasite might be dispersed by birds and mammals. A number of studies have been undertaken in the past five years to determine whether this is so. Birds have most frequently been considered the cause of isolated infections, the most striking of which is Arceuthobium oxycedri found on Juniperus brevifolia in the Azores 800 miles from the nearest source of infection (Ridley, 1930; Hawksworth and wiens, 1972). Zilka (1973) concluded that birds can potentially disperse mistletoe through daily bathing behavior, foraging and nest building where viable seeds are incorporated into nests.

Hudler (1974) found seeds of eastern dwarf mistletoe Arceuthobium pusillum on gray jays and a red squirrel (Tamiasciurus hudsonicus) though all were lured into infected brooms with suet before being caught. Hudler (1976) studied an infected area in Colorado where 32 isolated infection centers existed that were thought to have been dispersed by means other than explosive fruits. He found seeds on mist netted birds, but concluded that bird dissemination is a "rare and haphazard event."

One two-year study has addressed the role of small mammals in spreading dwarf mistletoe. Seeds were found on 
red squirrels and northern flying squirrels (Glaucomys sabrinus) one year (Ostry and Nicholls, 1975), and on red squirrels a second year (Ostry and Nicholls, 1976). Ostry (1976, personal communication) believes that both the red squirrel and the flying squirrel play a role in intensifying eastern dwarf mistletoe infections on black spruce and that the flying squirrel is a potential vector over larger distances.

\section{Purpose of study}

No study has been done in the western United States concerning dispersal of dwarf mistletoe by mammals. At the outset of the study it was determined that the red squirrel, the yellow pine chipmunk (Eutamias amoenus), the northern flying squirrel, and the bushy-tailed wood rat (Neotaoma cinerea) were all potential vectors of seeds. The red squirrel was chosen as the main object of study because it is diurnal and is closely associated with ponderosa pine (Pinus ponderosa), a heavily infected species. The study was undertaken to determine whether small mammals play a significant role in transporting mistletoe seeds to uninfected areas. Understanding their role can be helpful both in further understanding of the biology of dwarf mistletoe and in evaluating current control practices. 


\section{METHODS AND MATERIALS}

Two study areas were chosen along Graham Creek in the Malheur National Forest of eastern Oregon. Area A was located at an elevation of $1340 \mathrm{~m}$ and area $B$, which was one and a half miles south, was at $1700 \mathrm{~m}$ elevation. All behavioral data was gathered in area $\mathrm{B}$ where an area $1700 \mathrm{X}$ $900 \mathrm{~m}$ was marked off in a grid with unit dimensions of $30 \mathrm{X}$ 30m. The grid was marked off by stakes and by blue plastic flagging where branches were available. Each stake was given an $X$ and $Y$ coordinate number to enable quick identification of the location. When used in conjunction with a map, it was possible to plot accurately the location of any animal being observed in the study area.

The six squirrels that maintained territories within or nearly within the behavioral study grid of area $B$ were marked with Lady Clairol Ultra-Blue, which left a bright orange spot where it was applied. A simple code using marks on one, or at most two places on the squirrels' fur was used. In most cases marking was unnecessary because squirrels could be distinguished from each other either by their appearance or their behavior; almost all squirrels in the study were individually recognizable. Squirrels were live trapped in Tomahawk collapsable $5 \times 5 \times 18$ chipmunk traps and were baited with new pine cones. They were wary 
of traps and would not enter them for peanut butter, oatmeal, or walnuts, but would enter them readily to retrieve pine cones that had been taken from their caches. Squirrels could be retrapped within a few hours although no attempt was made to trap a squirrel more than three times. All successful trapping was on the ground.

Squirrels were observed from 19 August to 22 August, during which time their movements were recorded on maps and their activities noted. Informal observation took place from 17 June to 10 October; the four days of intensive observations from 19 August to 22 August adequately characterized the behavior and movement observed at other times. From the 19th to the 22nd, continuous notes were taken in coded form, and positions were plotted on a map. A position was marked for a given squirrel if it was performing vocalization, chasing, or cone gathering. The time of each behavioral sequence was noted adjacent to the code for the activity.

Squirrels were trapped or shot at twenty-five trap sites in area $B$ and at seven trap sites in area $A$ during the time of seed firing. No two traps were placed in the same squirrel's territory, so altogether thirty-two individuals were trapped. Trapped squirrels were etherized and examined for seeds on their fur and then released. Squirrels that were shot were checked for seeds, and stomachs were taken for content analysis. 
In area $B$, three Arceuthobium seeds soaked in a flourescent dye were placed under the tail of each of eight trapped squirrels. (This location was chosen because most seeds that had been found on trapped or shot squirrels were under the tail.) Sixteen to eighteen hours after seed emplacement, five of the squirrels were retrapped and examined for marked seeds.

Six out of seven trap sites were evaluated for intensity of mistletoe infection in area $A$, and six out of twentyfive trap sites were evaluated in area B. Figure 2 shows the sampling pattern. The method of evaluating sites was as follows:

1) In area $B$ the cone cache nearest the approximate center of the territory (if known) was chosen as the center of the trap site evaluation. In area $A$ where territories were not known, the center of the trap site evaluation was placed at the largest cone cache used by the squirrel. The largest cone cache was used as the estimator of the center in area $A$ and area $B$ where territories were not known because most observations in area $B$ showed the major cache to be near the center of the territory. The trap site evaluation center was placed near the center of the territory because it was thought to be the best approximation of the intensity of mistletoe infection through which the squirrel regularly traveled.

2) After the center of the trap site evaluation had 


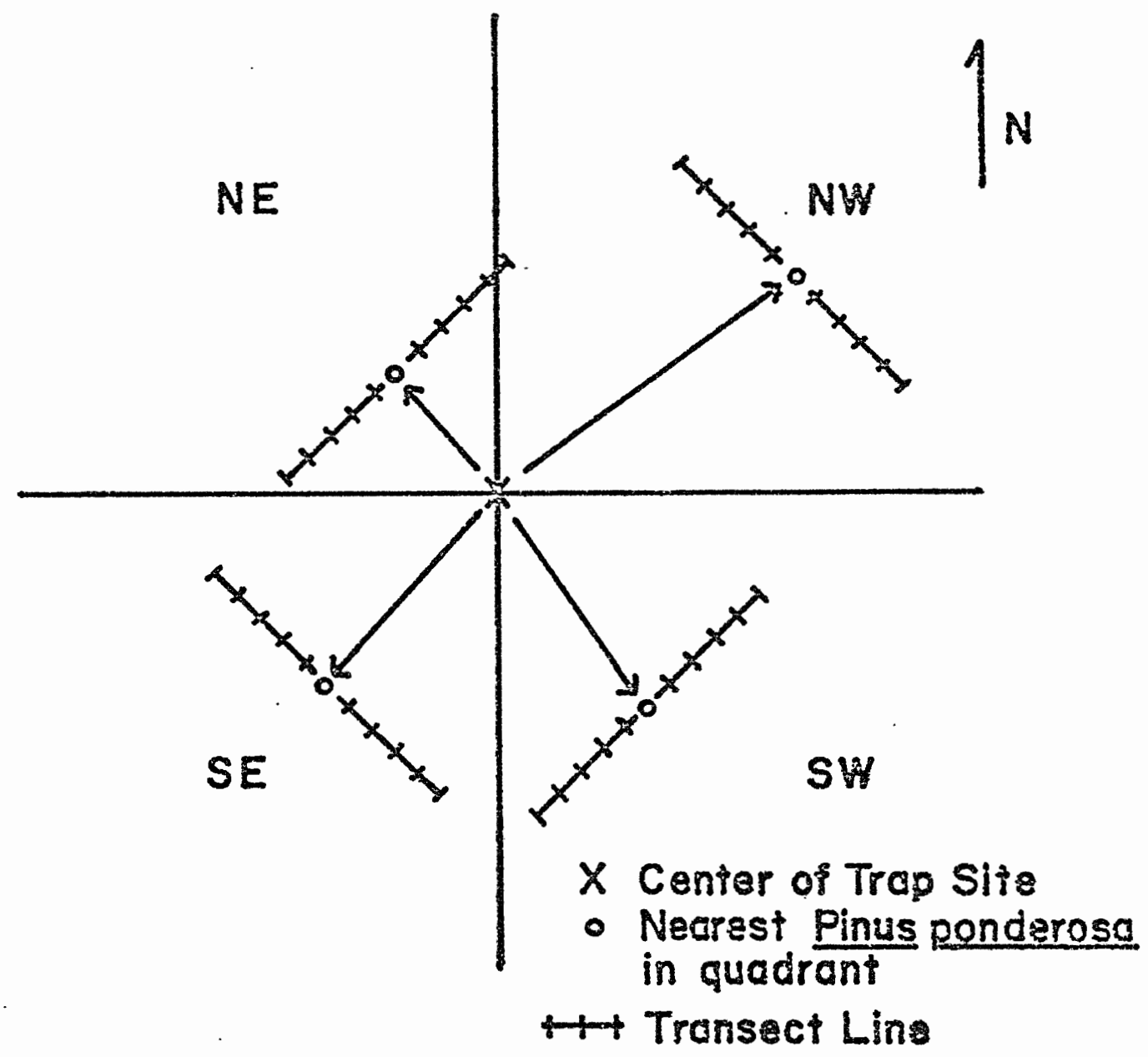

Figure 2. Trap site evaluation sampling pattern. 
been chosen, a compass was used to establish the northeast, northwest, southwest and southeast quadrants of the site. Once quadrants had been determined, each was evaluated separately.

3) In each quadrant, the overstory ponderosa pine nearest the center of the site was chosen as the midpoint of a Iine transect. This choice was made because pine squirrels were feeding almost exclusively on ponderosa pine cones and consequently most of their time was spent in the trees of this species.

4) From the midpoint tree in each quadrant, a line transect was established with a compass. The transect was established at a forty-five degree angle from the northsouth, east-west coordinate of the site, so that in the northeast quadrant the transect ran in a northwest-southeast direction. In the northwest quadrant the transect ran in a northeast-southwest direction, and so on.

5) After the midpoint tree in the line transect was characterized for infection, five trees on each side of the tree were evaluated at $5,10,15,20$ and $25 \mathrm{~m}$ along the transect in each direction. The nearest tree to each of these intervals along the transect was sampled. If no tree was within $5 \mathrm{~m}$ of the point on the transect being evaluated, a blank was left. No tree was evaluated twice.

6) The species diameter at breast height (DBH) and degree of infection were recorded for each tree sampled along the transect. 
7) The degree of infection was rated as follows:

Rating

Description

$0 \quad$ No brooms or infections

1 Broomed with no visible infections

2 1-3 infections; no brooms - slightly broomed

$31-3$ infections; heavily broomed

$44-6$ infections; slightly broomed

$54-6$ infections; heavily broomed

$7 \quad 7-10$ infections; heavily broomed

9 11-15 infections; heavily broomed

$11 \quad 16-20$ infections; heavily broomed

1321 and above in number of infections

The above method of rating was chosen over other methods (Baranyay and Smith, 1972; Hawksworth and Wiens, 1972) because, as it is a strictly quantitative method, it best delineates differences in degrees of infection. A distinction in rating was made between slightly and heavily broomed trees with the same number of visible infections because it was assumed that some infections were missed in the heavily broomed trees. 


\section{RESUITS}

\section{Behavior}

Figure 3 shows the results of four days of observation of pine squirrel activity. Feeding and cone caching, territorial behavior and grooming all appeared to have three peaks of activity between 0600 and 1800 hours, though observation time (12 continuous hours) was too limited to indicate whether this was so. When the pine cones ripened, the activity pattern of the squirrels in this study changed somewhat; they became more uniformly active throughout the day.

The predominant activity from early August to early October is gathering and storing pine cones. Two patterns of hoarding cones exist. In one pattern the squirrel ascends a tree, takes a cone from the end of a branch and descends, carrying it up to $120 \mathrm{~m}$ to bury it in a cache. In the second pattern, the squirrel ascends to the branch tips where cones are found and cuts as many as sixty at a time from the same tree, or from trees with adjacent overstories, before descending to the ground to carry the cut cones to a cache. Squirrels would often travel farther than $120 \mathrm{~m}$ at a time when not carrying cones. It was found that the mean distance between the two farthest points where any one squirrel was seen was $139 \mathrm{~m}$ with a standard deviation of $40 \mathrm{~m}$. 


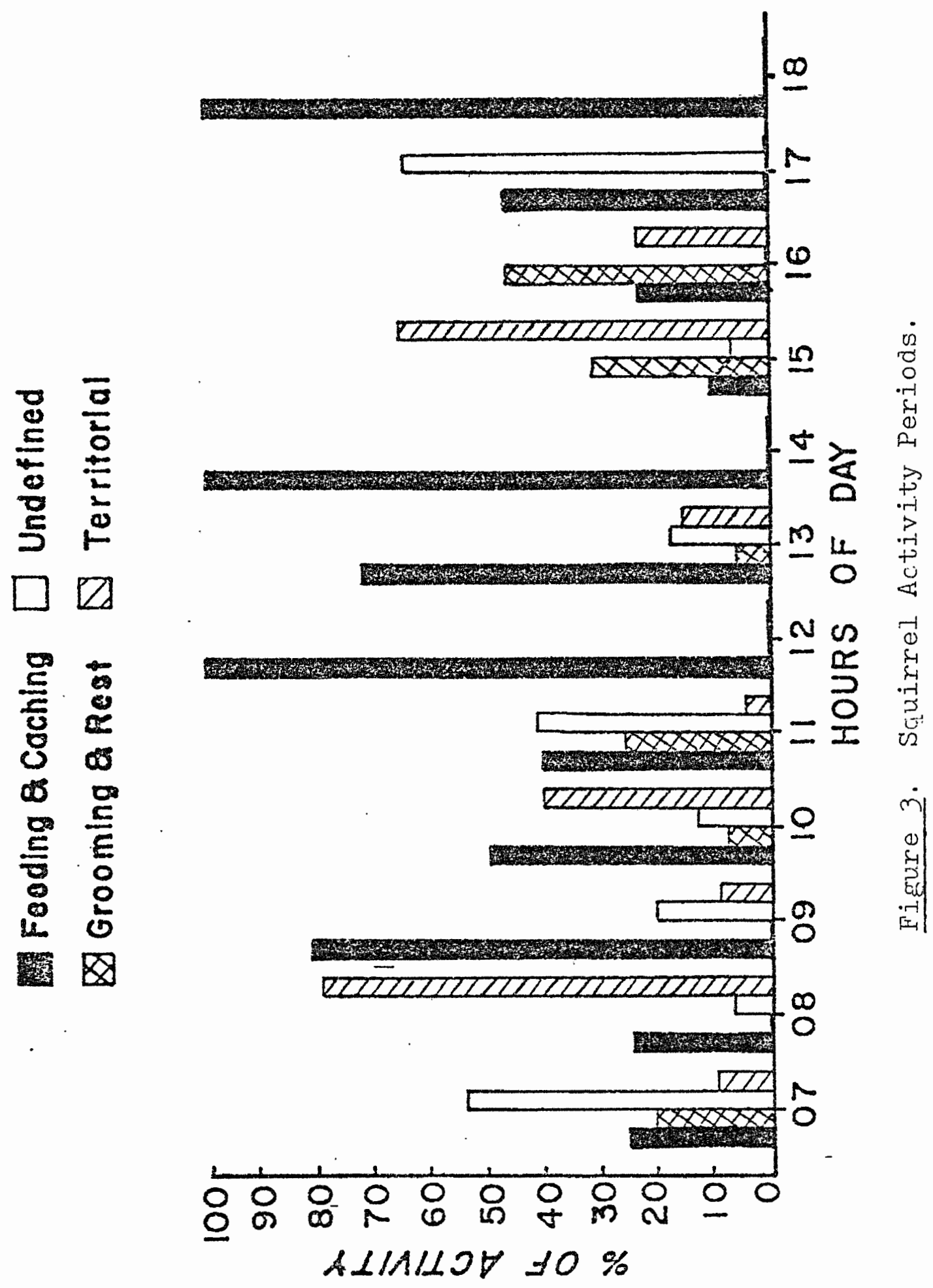


Squirrels often traveled this far in a few minutes' time.

Stand Evaluation

Table I summarizes the measured differences between the two stands. While ponderosa pine is clearly the dominant species at both sites, its dominance is less pronounced at area $B$ where white fir (Abies concolor) and Douglas fir (Pseudostuga menziesii) are important understory species. The ponderosa pine of area $B$ are significantly larger than at area $A$ which probably has been cut more recently. Area A is more open than area B; of 264 sample points at each study area, $31(13 \%)$ in area $A$ are devoid of trees and 12 (5\%) at area $B$ are treeless. Area A has a much higher infection index than area $B$.

During the summer of 1976 only ponderosa pine cones developed in both study areas, so most squirrel activity was in that species. No cones of other species were found in caches, with the exception of a small number of Engleman spruce (Picea englemannii) cones in one cache in area $B$ and some white fir cones in area A. Since ponderosa pine was clearly the most important tree to the pine squirrel and very few of the other species were infected (3.6\%), this study limits itself to infection intensity in the ponderosa pine in the study areas.

Figure 4 summarizes the degree of infection found in the two study areas. The mean DBH and mean infection index for each trap evaluation site within the study areas are 


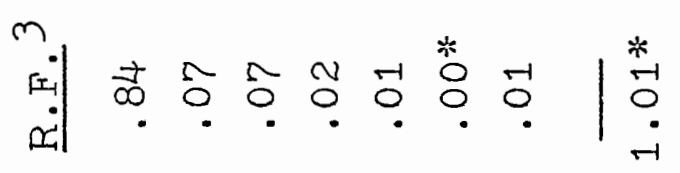

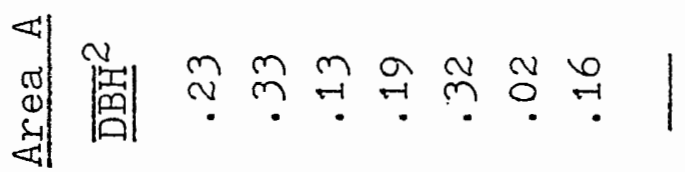

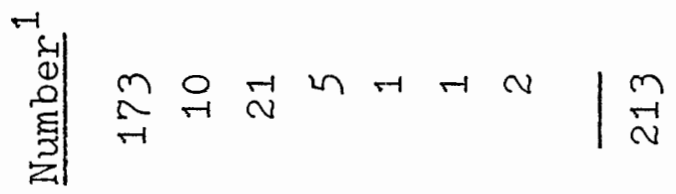

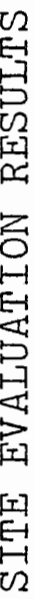
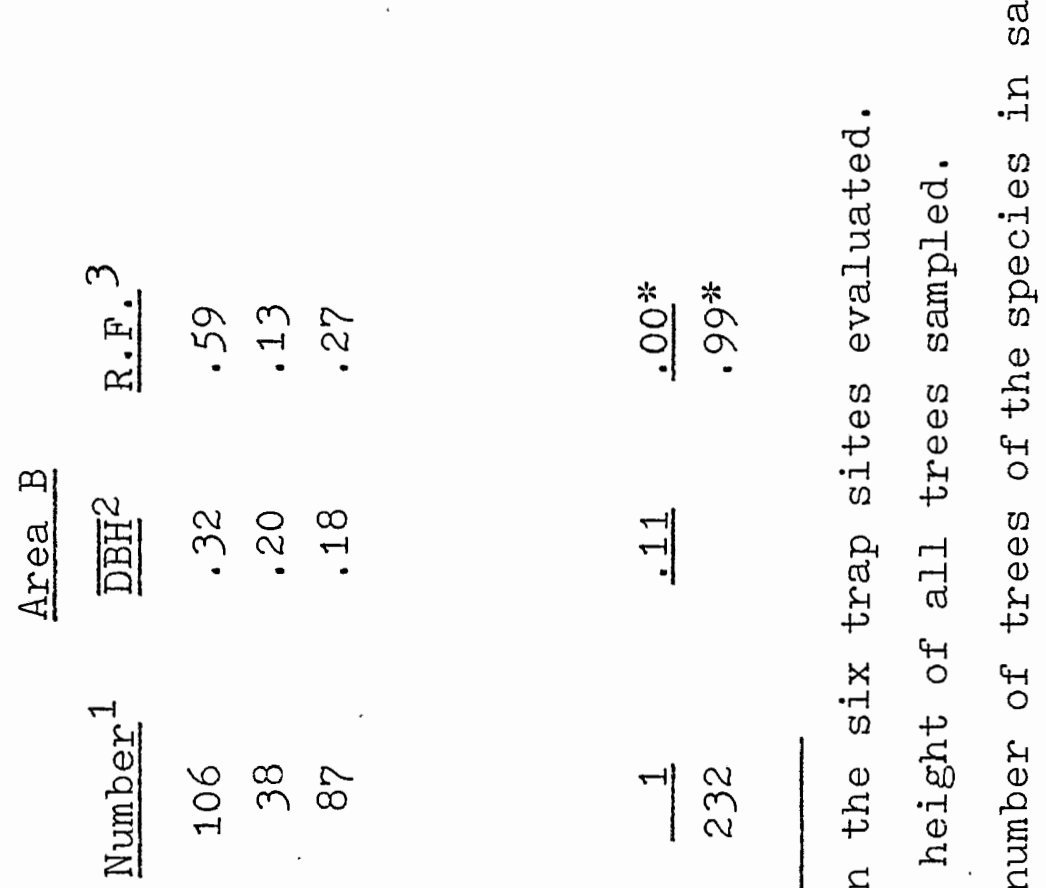

近

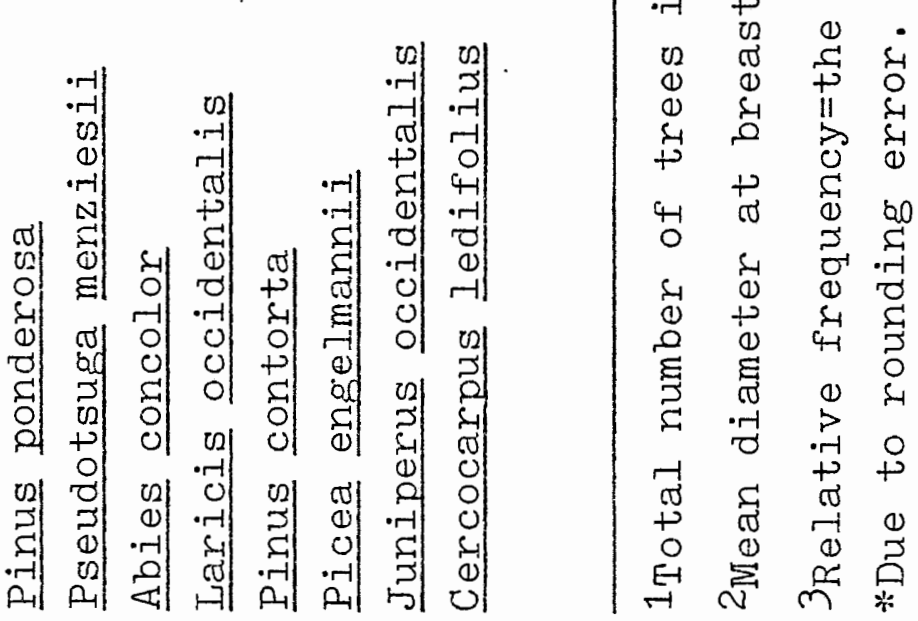



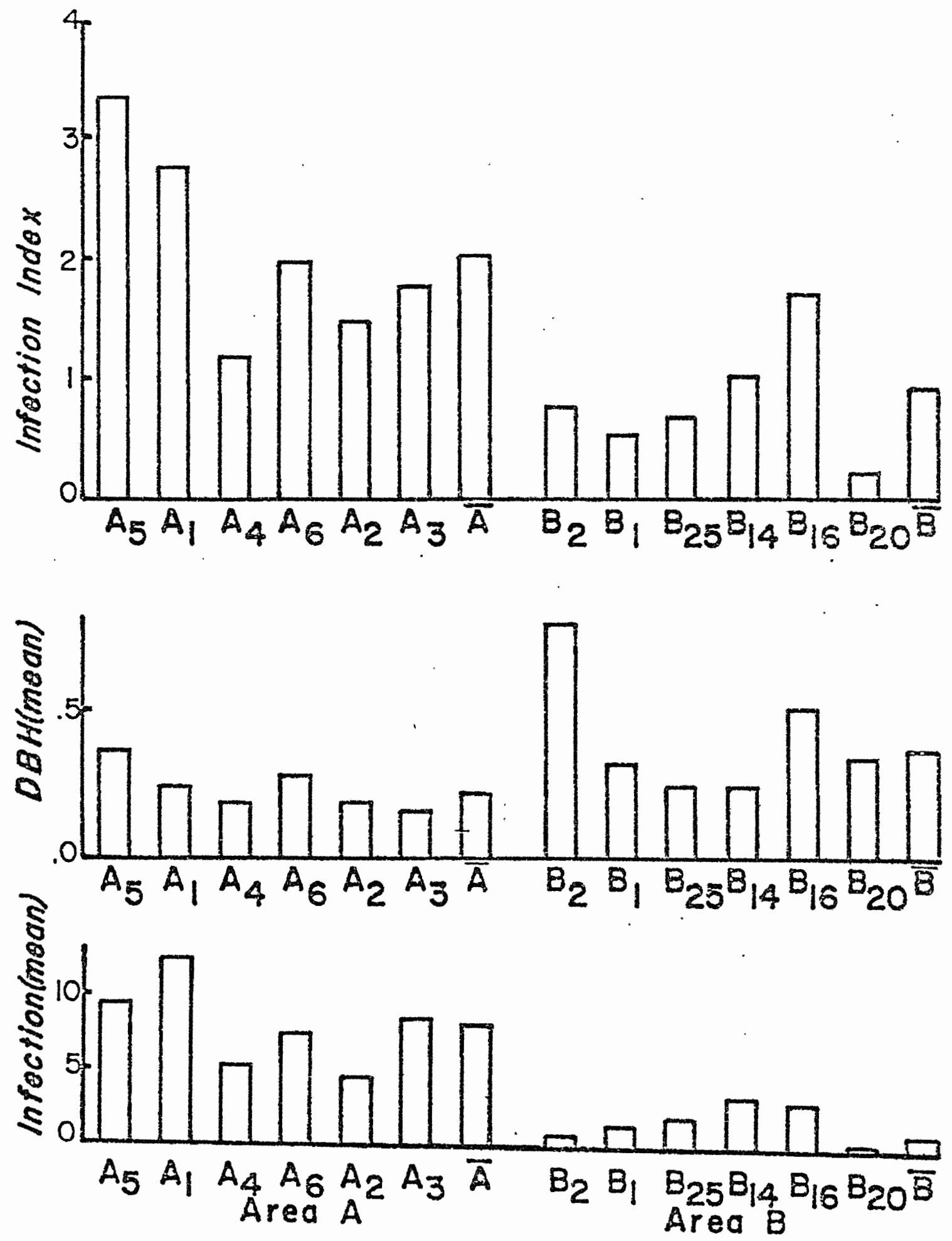

Figure 4 . Infection indices of area $A$ and area $B$. 
shown to indicate the importance of each parameter in determining the trap site infection index (I). The index (I) is the sum of the products of the $\mathrm{DBH}$ and the infection index of each tree sampled. The calculation of I is shown in equation 1 .

$$
I=\sum_{i=1}^{44} \mathrm{DBH}_{i} X t_{i}
$$

When the means of each sampling site within the two areas are combined, the resulting mean is an estimator of the overall difference between infection in the two study areas, $A$ and $B$. The difference in infection between the two study areas is pronounced, while the difference in mean DBH between the two areas is minimal.

\section{Trapping And Shooting}

By September 13, some seeds in area A were ripe enough to fire when physically disturbed; fewer seeds could be caused to fire in area $B$. The seeds in area $B$ may have been one to two weeks behind area $A$ in development due to the higher elevation and reduced insolation. Trapping and shooting of squirrels was begun on 18 september in both areas, since by this time seeds were firing without being disturbed. Trapping was discontinued on the 19th, and begun again for two final days on the 20th and 21st. At that time the majority of seeds had not fired, but it was not possible to remain in the field for further observations. 
The results of shooting and trapping in the two study areas are shown in Table II and Figure 5 .

Eight squirrels were tagged with two to three seeds each and were released. Within 16 to 18 hours of their release, 5 were retrapped and checked for seeds. Of a total of 13 seeds placed on these 5 squirrels, 2 (15\%) were recovered, one on each of two squirrels. 
TABIE II

TRAPPING AND SHOOTING RESUITS

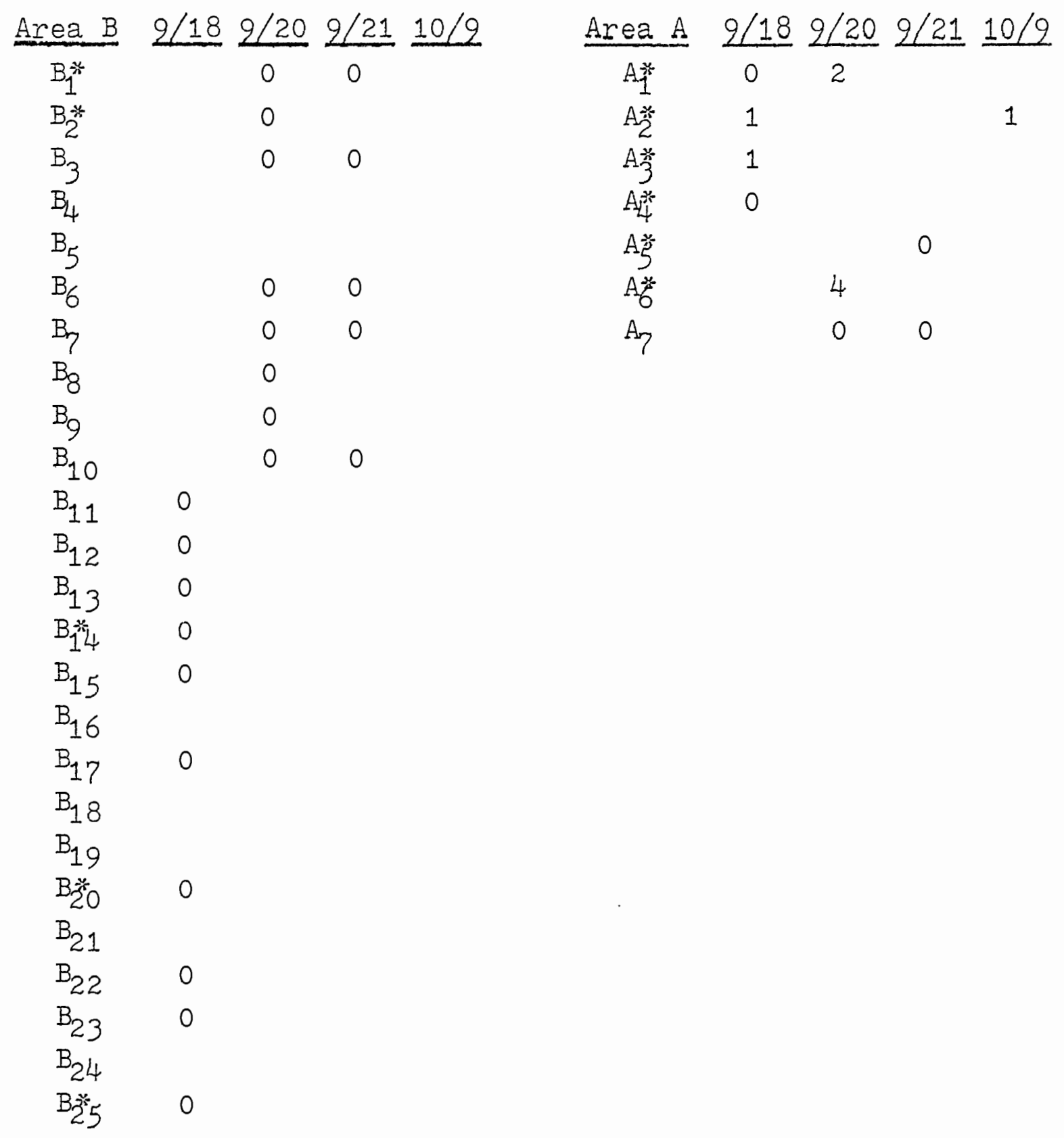

*Included in trap site evaluation. 


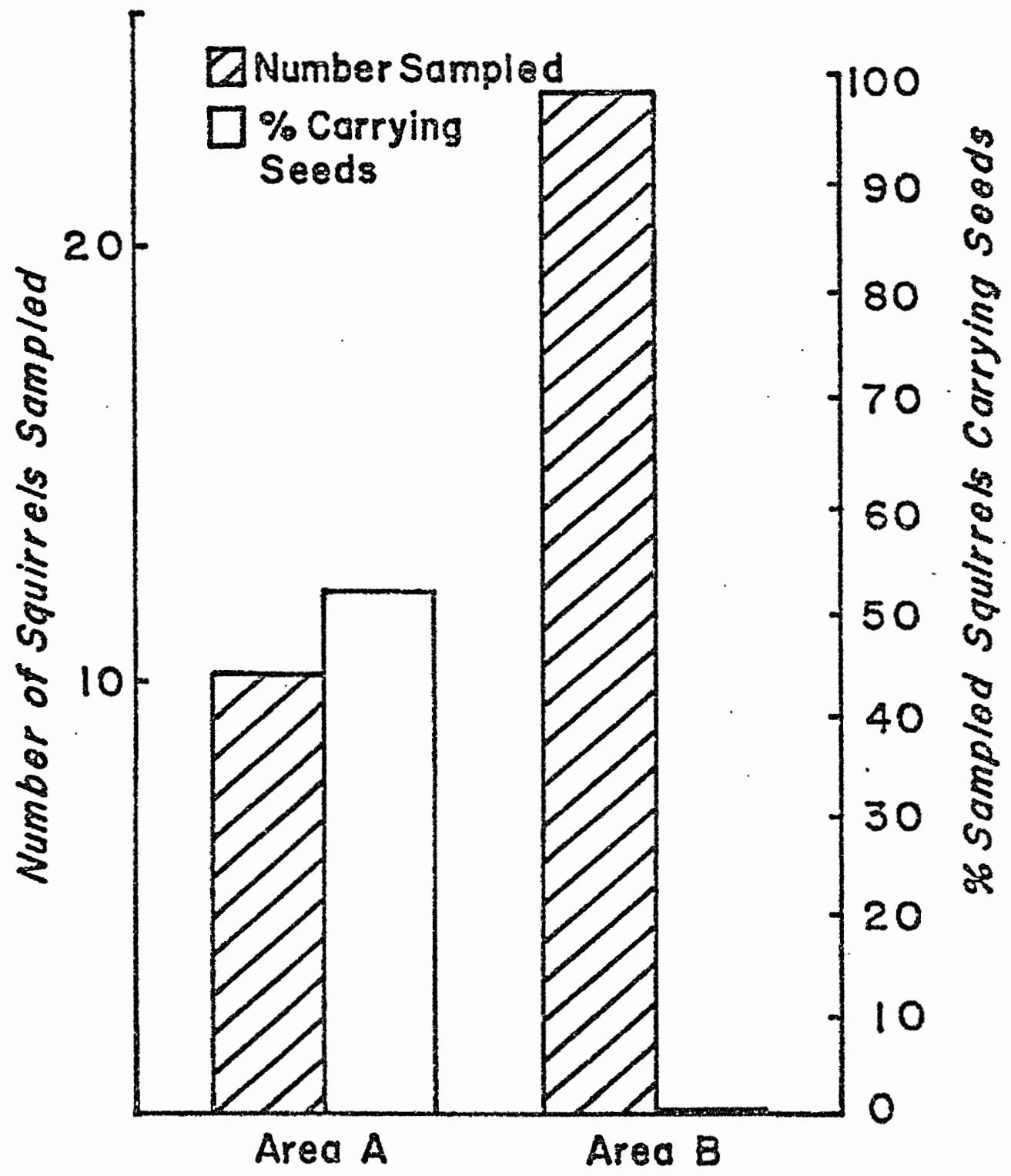

Figure 5. Trapping and shooting results. 


\section{DISCUSSION}

Three factors determine the significance of small mammals in the dispersal of mistletoe: (1) the potential for contacting and carrying ripe seeds, (2) the distance over which seeds can be carried, and (3) the potential infectability of tree tissues where seeds are dislodged. This study provides preliminary data for each factor.

Potential For Intercepting Mistletoe Seeds

Avoidance of Mistletoe. In a normal year the pine squirrel is actively gathering cones all fall. Squirrels discriminate between species of trees on the basis of a number of cone characteristics (Smith, 1970: Elliott, 1974) and generally harvest their preferred species entirely before moving on to the next preference for foraging. It is this preference that determines which trees will be visited most frequently by squirrels. The fall of 1976 was unusual because only ponderosa pine produced cones. Examination of cone scales left from 1974 and 1975 showed that other species, namely Douglas fir, white fir and Englemann spruce had been used in those years, although ponderosa pine was still the most frequently used. With only ponderosa pine cones available for forage, squirrels spent nearly all of their time in ponderosa pine trees. 
Squirrels discriminate between trees of the same species according to cone morphology and the number of seeds per cone (Elliott, 1974), and also possibly on the basis of the number of cones per tree. Mistletoe brooms are usually sterile and do not bear cones (Kuijt, 1960; Bonga, 1964); therefore, it is possible that heavily broomed trees are chosen last by squirrels. Whether or not this is the case, squirrels most likely do not move through many brooms simply because brooms have essentially no cones, thus they spend the most time in uninfected portions of an infected tree.

No study time was allotted to behavior during seed firing to determine whether squirrels are sufficiently bothered by the explosive seeds to avoid aerial shoots. Such an alteration in behavior would greatly affect their seed-carrying potential.

Infection Index. Considering that squirrels may spend more time in healthy foliage than in infected foliage, the probability of encountering seeds rises with increasing infection simply because there is proportionately less uninfected cone bearing area. The encounter probability, as used here, is the probability of finding one or more seeds on a squirrel sampled at random from the population and is related to the actual number of squirrels carrying seeds. The encounter probability relates to seeds that have dried on the squirrel's fur and not seeds carried a short distance and lost before the six to ten minute drying time. 
The fate of these seeds is discussed later.

Figure 4 shows the difference in the infection index in the two areas in this study; clearly the likelihood of contacting a mistletoe seed is higher in area $A$ than in area B. The data support this conclusion. Of ten squirrels captured in area $A$, five squirrels carried from one to four seeds. Of 23 squirrels captured in area $B$, no animals were found with seeds on them.

A possible interpretation of these data is: even though there were numerous infections in area $B$, the sample size was too small to include the random occurrence of seed encounter by a squirrel. Alternatively, and more likely, few enough branches were infected that squirrels could easily avoid them while foraging. A low probability for the random interception and a high ability for remaining in uninfected foliage make the probability of seed encounter in area $B$ essentially zero. In area $A$ there is a high probability of seed encounter of a purely stochastic nature, coupled with a low ability to remain only in uninfected branches while traveling and foraging. Without an increase in energy expenditure, avoidance is nearly impossible and, therefore, the probability of seed encounter is approximately $50 \%$ as indicated by the sampling carried out.

The relationship between encounter probability and intensity of infection may be linear, but it seems reasonable to assume that due to the tendency of squirrels to inhabit 
healthy branches, there is a threshold level below which the stochastic element is too low, and the extra energy required to frequent only uninfected foliage is low enough that the encounter probability is essentially zero. Above the threshold level, the encounter probability may actually rise in a curvilinear fashion. Figure 6 is the relationship postulated. Area $B$ is below the threshold level, and there is no indication how far below. Area $A$ is near the 50\% level, which means that there is a $50 \%$ chance of finding at least one seed on a squirrel chosen at random at any time during or after a peak activity period. A small increase in the infection index would probably greatly increase the encounter probability.

Two factors may alter this scheme somewhat. First, it may be that the data are biased due to the time of sampling in area $B$ where seeds may have been one to two weeks behind area $A$ in maturity. No quantitative measurements were made to test this possibility because of time limitations. Secondly, the data are likely to be biased due to the sampling time during the day. The number of seeds found in area $A$ seems to be more strongly correlated with the time of squirrel capture than with the infection index. Note that in trap site $\mathrm{A}_{5}$, which had the highest index, no seeds were found in two samples; both of these samples were taken in the early afternoon (between 1300 and $1500 \mathrm{hrs.}$.). In $A_{3}$, which had the lowest index in trap site $A$, one seed was 


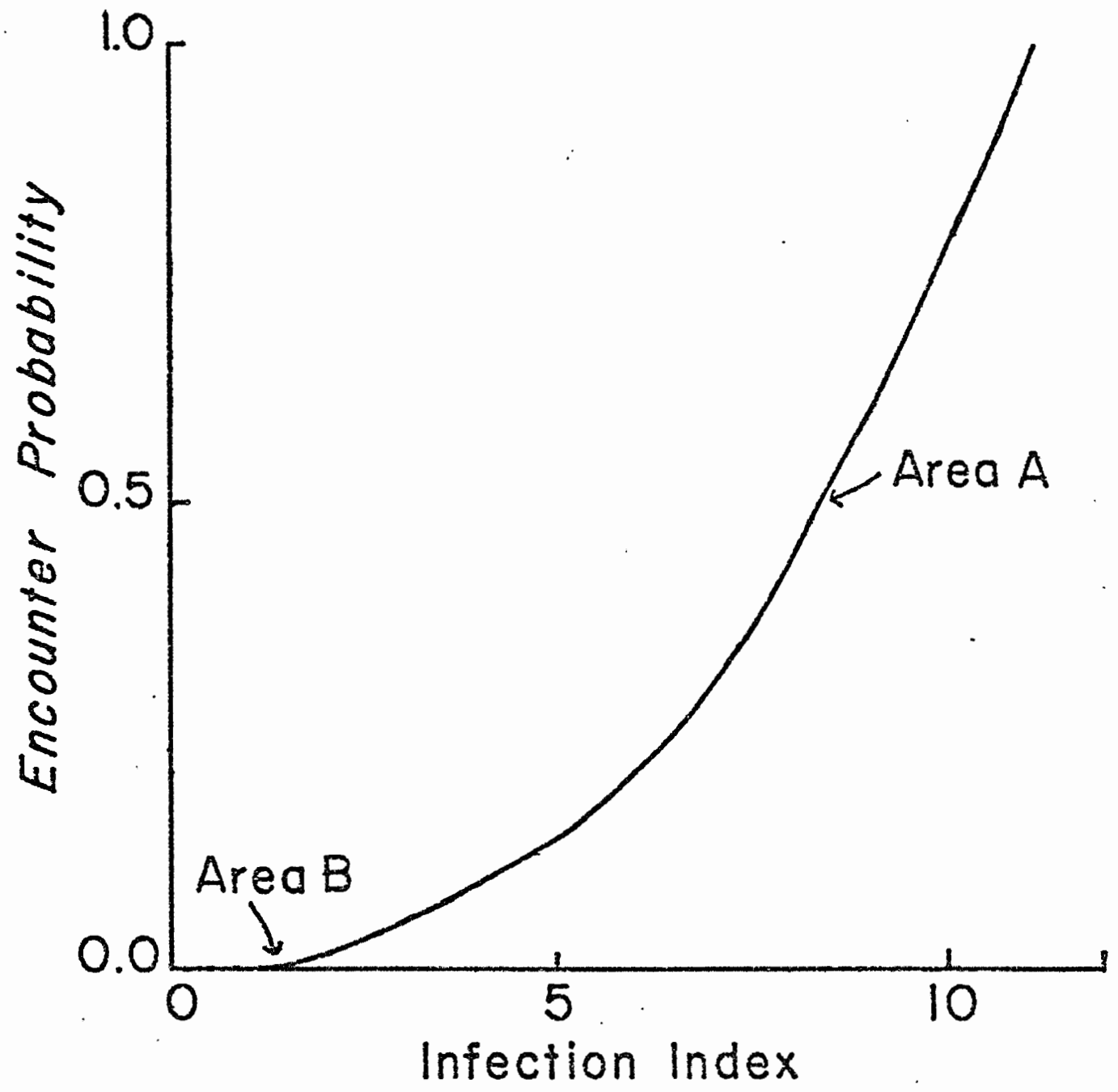

Figure 6. Proposed relation of encounter probabilities to infection indices. 
found out of one sample which was obtained in late morning (1115 hrs.). The time when the most seeds were found was $1050 \mathrm{hrs}$. $\left(\mathrm{A}_{6}\right)$, which coincides with the time in which morning foraging activity has just peaked; it is also the earliest sample from area $A$. If other samples in area $A$ had been taken earlier, both the number of seeds and the percentage of animals carrying seeds would have been significantly higher.

Prediction of Yearly Seed Encounter. The behavioral part of this study indicates three daily peaks in foraging activity each day, and consequently, there are three times daily when seed encounter probability is high. Seeds were found on squirrels from 18 September to 9 October--a twentytwo day period. There were at least 66 times (three activity periods per day X 22 days) when encounter of seeds was probable if the infection index were high enough. In area B no seeds may have been encountered at all, but in area A the number of seeds carried by any given squirrel is predicted to be at least 59.4 seeds per year $(66$ peak encounter times $X .50$ probability of encounter $X 1.8$ seeds per encounter). Since the estimate of $50 \%$ encounter probability is probably biased downward due to the time of sampling in the study, the actual number of seeds carried may be more than 59.4 per year.

There are three parameters in the above prediction: activity periods, length of the fruiting season, and 
encounter probability. Encounter probability is determined by the infection index and species usage. If the values are known, then useful predictions can be made about the number of carried seeds in a season.

Distance of Seed Dispersal

The pine squirrels in this study traveled from 80 to $120 \mathrm{~m}$ to cache cones. In more than half of the incidents of caching observed, only one cone was cut and carried at a time, while a few squirrels cut up to sixty cones before descending to carry them to their cache. Whether squirrels descended for each cone or cut a number at a time, they were potential vectors for mistletoe seeds over short distances as they moved from branch tip to branch tip. The result of: this spreading would be intensification in adjacent trees from seeds picked up by the fur and dislodged again before drying occurred. These seeds would rarely be included in a sample obtained from trapping.

During intensive cone gathering, squirrels are seldom observed grooming and may tend to accumulate seeds. During the first lull in activity when squirrels tend to withdraw to trees near their caches, detected seeds are probably groomed from their fur. It may be that grooming also occurs during foraging when seeds are detected. The fact that all seeds found on squirrels, with one exception, were on the tail in places that would have been difficult to detect, regardless of the time of capture, is evidence for this 
point. Either seeds are groomed off during caching activity, or most seeds that are intercepted strike the tail.

The general movement of seeds not lost before drying and not groomed off during active foraging would be toward the area around the main cache where they would be dislodged during grooming. The cache area is the likely destination of the sixty seeds carried during one season.

The two patterns of distance dispersal of seeds are short-range, local infections and long-range movement into the territory center. Both could be detectable patterns, although the latter is more likely to be observed.

Pine squirrels are know to be territorial and Smith (1968) found them to have clearly delineated territories with ownership of individual trees recognized. Territories are not stable over a period of time, however, and boundaries shift as vagrant squirrels take spaces of dead squirrels or squeeze new territories between existing ones. In the four to five years from seed dispersal to flowering and reproduction, the shape of territories will have changed greatly, and what was once the center of a territory could be near the edge.

In many instances, infections resulting from grooming near the territory center would be satellite infections. If these satellite infections eventually came to be at the edge of another squirrel's territory, they could serve as stations along a dispersal path. Figure 7 illustrates such 


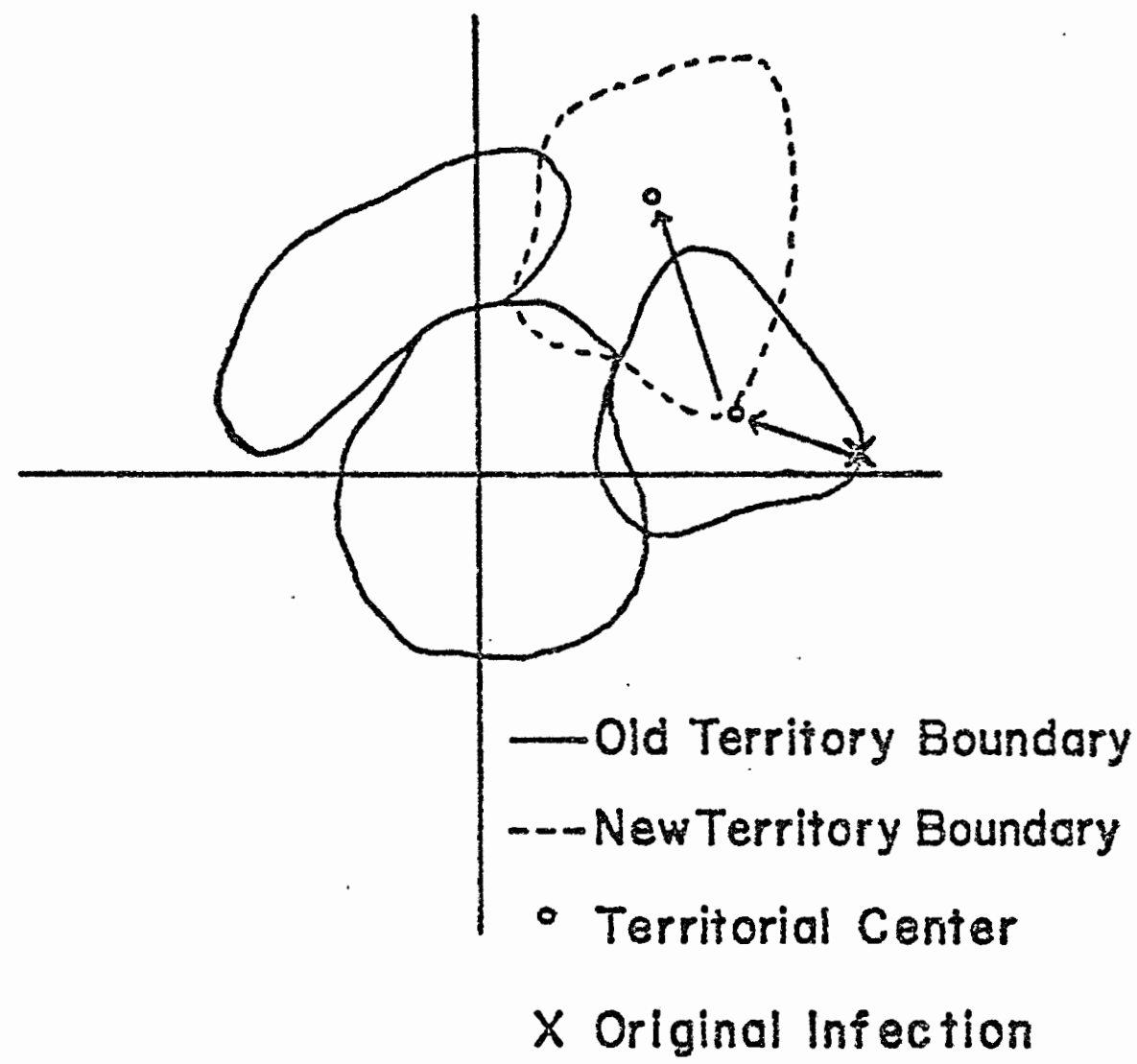

Figure 7. Possible route of infection seed advancement. 
a dispersal pattern. Whether this indeed occurs is uncertain, but it is a testable hypothesis and could be ascertained by the appropriate analysis of certain stands where satellite infections exist. Such analysis already has been done by Hudler (1976) concerning bird dispersal.

Hudler (1976) reported that the viscin cells of mistletoe seeds dry in six to ten minutes on cotton cloth and suggested that they may dry somewhat more slowly on animal fur. Often pine squirrels were observed to forage in several locations alternately; this could result in a third dispersal pattern where moist seeds are carried from an inoculum source to the cache and to a second area being foraged. Such movements can occur in a few minutes' time.

\section{Infectability}

Having discussed the likelihood of squirrels encountering seeds and the likely patterns of seed dispersal, the question remains as to how many dispersed seeds ever germinate in a susceptible part of an appropriate host tree. In ponderosa pine a seed will typically produce an infection only in growth up to five years old (Hawksworth, 1954). Seeds that are groomed off near the bases of branches will not likely cause infection.

Most of the grooming observed took place at the bases of branches where there was little chance of successful germination. Occasionally mistletoe seeds might be annoying enough to elicit grooming during activity, but how many 
of those seeds could lodge on infectable branches is unknown. Seeds that have dried on animal fur have to be vigorously pulled to be extricated and, when pulled by teeth, may be injured. Also, such seeds are dry and will not stick to pine needles and would have to lodge in the bark of the branch. Seeds that are carried only a few minutes and dislodge during foraging stand a considerably better chance of sticking to a susceptible branch.

Hawksworth (1965) and Wicker (1967) have shown that only $6 \%$ to $14 \%$ of seeds securely adhering to pine branches ever successfully infect the host. This is due to attrition caused by such things as snow, rain, insects, molds, rodents and birds. A single heavily infected overstory tree may produce from 800 to 2,000,000 seeds in a single year and yet successfully infect very few new trees due to these klendusic factors. These facts suggest that squirrels that carry sixty seeds a year, most of which probably fall in inhospitable locations, make little contribution to longrange spread. A new infection may result even more infrequently from squirrel activity than from bird activity (Hudler, 1976). The principle problem in knowing for certain whether or not this is true is that the actual destiny of seeds is not known.

\section{Role of Other Mammals}

Three other species of mammals are potential mistletoe vector. The bushy-tailed wood rat (Neotoma cinerea) very 
likely nests in old witches brooms of ponderosa pine. A number were observed climbing into brooms after release from traps. Their limited home range rules them out as longdistance vectors, but their herbivous habits make them potential local intensifiers of infection.

The yellow pine chipmunk (Eutamias amoenus) actively gathers seeds in ponderosa pine during the mistletoe fruiting season and has been observed eating mistletoe seeds (Wicker, 1967). Though less consistently active in ponderosa pine, they may affect mistletoe dispersal somewhat.

The northern flying squirrel (Glaucomys sabrinus) could be a long-distance vector because it has a larger home range than the pine squirrel and has been known to carry seeds in the East (Osprey, 1975; personal communication). As it is strictly arboreal, the potential for carrying seeds to other trees is higher than for the pine squirrel, though the flying squirrel encounters far fewer seeds. It is also suspected that the flying squirrel nests in brooms in the summer, as does the pine squirrel.

None of the above three species is as active as the pine squirrel in young, needle-bearing branches where mistletoe is likely to be found. Each has, however, a potential to transport seeds. 


\section{CONCLUSION AND RECOMMENDATIONS}

The pine squirrel is a vector of mistletoe seeds with its most significant impact on intensification of infections within an already infected tree and adjacent trees. While the area of the main cache is likely to be the destination of most seeds groomed from the fur, most of the seeds will not fall onto an infectable tissue. The degree to which local intensification occurs depends upon the intensity of infection in the stand. Below a minimum level of infection this probability approaches zero. Beyond a threshold level of infection the probability of seed encounter rises rapidly with increasing infection.

When a stand has been initially infected, no seeds are likely to be dispersed from it by squirrels until the satellite infection index passes the threshold level. Once that level is reached, squirrels will intensify infection near the original infection and occasionally even will inoculate a tree near their cache. When a tree near the center of the home range is inoculated and reaches a threshold level, it may serve as an inoculum source, although that would require a number of years.

The above prediction rests on educated speculation about the ultimate destination of carried seeds. Further study is needed to verify what in fact happens to intercepted 
seeds. The fact that such information is difficult to procure is attested to by its absence in this study and any other on the subject. In spite of the difficulty it would be well worth the effort.

The following are suggestions for further study on this topic:

1) Study several plots with infection indices intermediate between the two in this study to establish more convincingly the relationship between the infection index and the seed encounter probability.

2) During the fruiting season quantify the amount of seed discharge through the day and through the season for use in prediction of seeds carried.

3) By a trap-release-retrap procedure, coupled with observation, attempt to discern the fate of seeds on squirrels' fur.

4) Note the behavior of squirrels with reference to aerial shoots during the fruiting season.

5) Gain a better understanding of grooming behavior in the field by observation and experimentation.

6) Find an area of spotty or slight infection near an area of moderate infection and attempt through pattern analysis to determine whether satellite infections could be explained by squirrel dispersal.

7) Though other mammals may disperse seeds, the difficulty of studying them, coupled with the probability 
that their importance is minimal, makes them less than desirable as subjects for further study on this question.

Finally, this study has some relevance concerning forestry practice. Several methods of sanitation are used to contain mistletoe infections, including clear cutting, strip cutting and pruning. In rare cases squirrels may carry seeds into new growth in clear cuts from adjoining infected trees. However, this is unlikely, since, because of their intensive cone gathering, squirrels rarely enter small trees during fruiting season. Generally, by the time a regenerating clear cut is of interest to squirrels, the adjoining infected trees will have been cut and the inoculum source will be gone. The clear cut in area $A$ of this study acted as barrier and no squirrels crossed it; this was presumably due to increased exposure to predators.

Cutting a strip between infected and uninfected trees may be of limited usefulness unless it is broad enough to act as a barrier to squirrels. A swath in area $A$ of this study did not act as a barrier and seeds were no doubt carried across. Finally, control measures by pruning all branches between an infected lower story and the uninfected crown (Knutson, 1976) is probably the most affected by squirrel activity. The transportation and displacement of moist seeds as squirrels forage throughout the tree would quickly inoculate the upper story of the tree, thereby negating the effectiveness of pruning. 


\section{IITERATURE CITED}

Baranyay, J. A. 1968. Squirrel feeding on dwarf mistletoe infections. Can. Dept. Forest Bi-Mon. Prog. Rept. 24 $(5): 41-42$.

Baranyay, J. A. and R. B. Smith. 1972. Dwarf mistletoes in British Columbia and recommendations for their control. Can. Forest Serv. Pacific Forest Research Centre, $\mathrm{BC}-\mathrm{X}-72$.

Bonga, J. M. 1964. An unusual witch's broom on black spruce caused by eastern dwarf mistletoe. Forest Sci. $10: 77-78$.

Broadbrooks, H. E. 1958. Iife history and ecology of the chipmunk Eutamias amoenus in eastern Washington. Univ. Mich. Zool. Misc. Publ. 103. 15p.

Clarkson, David P. and Homer J. Ferguson. 1969. Effects of temperature upon activity in the red squirrel. Amer. 2001. 9(4):1110.

Dahms, W. G. and J.W. Barrett. 1975. Seed production of central Oregon ponderosa and lodgepole pines. USDA For. Serv. Research Paper PNW-191.

Elliott, P. E. 1974. Evolutionary responses of plants to seed-eaters: pine squirrel predation on lodgepole pine. Evolution 28:221-231.

Gill, I. S, and F. G. Hawksworth. 1961. The mistletoes: a literature review. US Dept. Agric. For. Serv. Technical Bull. 1242.

Hawksworth, F. G. 1954. Observations on the age of lodgepole pine tissues susceptible to infection by Arceuthobium americanum. Phytopathology 44:552.

Hawksworth, F. G. 1958. Rate of spread and intensification of dwarf mistletoe in young lodgepole pine stands. J. of Forestry 56:404-407.

Hawksworth, F. G. 1965. Iife tables for two species of dwarf mistletoe I. Seed dispersal, interception and movement. Forest Sci. 11:142-151. 
Hawksworth, F. G. and D. Wiens. 1972. Biology and classification of dwarf mistletoes (Arceuthobium). U.S. Dept. Agric., For. Serv. Agric. Hndbk. 401. 231pp.

Hudler, G., T. Nichols, D. W. French and G. Warner. 1974. Dissemination of seeds of the eastern dwari mistletoe by birds. Can. Jor. For. Res. 4(3):409-412.

Hudler, G. W. 1976. Bird Dissemination of Arceuthobium vaginatum Subsp. Cryotopodum. Ph.D. Thesis, Colorado State University, Fort Collins, Colorado.

Hudler, G. and D. W. French. 1976. Dispersal and survival of seed of eastern dwarf mistletoe. Can. Jor. For. Res. 6(3):335-340.

Ingles, I. G. 1947. Mammals of the Pacific states. Stanford University Press, Stanford, Calif. 506p.

Keith, J. 0. 1965. The abert squirrel and its dependence on ponderosa pine. Ecology 46(1):150-163.

Knutson, D. M. 1975. Dwarf mistletoe-infected ponderosa pines survive top-pruning. J. of Forestry 73(12).

Kuijt, J. 1960. Morphological aspects of parasitism in the dwarf mistletoes (Arceuthobium). Univ. Calif. Pub. Bot. $30(5): 337-436$.

Kuijt, J. 1969. The biology of parasitic flowering plants. Univ. Calif. Press, Berkeley, Calif. $246 \mathrm{pp}$.

Layne, J. N. 1954. The biology of the red squirrel (T. hudsonicus loquax) in Central New York. Ecol. Monographs 24:227-267.

Myers, C. A., F. G. Hawksworth and P. C. Iightle. 1972. Simulating yields in Southwestern ponderosa pine stands, including effects of dwarf mistletoe. USDA For. Serv. Research Paper RNI-87. 16p.

Ostry, M. E. and T. H. Nicholls. 1975. The role of animal vectors in the long distance spread of eastern dwarf mistletoe of black spruce as determined by radio telemetry. USDA For. Serv. North Central Forest Exp. Station Prog. Rept. 1. (Unpublished).

Ostry, M. E. 1976. Personal communication. USDA For. Serv. North Central Exp. Station.

Ostry, M. E. and T. H. Nicholls. 1976. The role of animal vectors in the long distance spread of eastern dwarf 
mistletoe of black spruce as determined by radio telemetry. USDA For. Serv. North Central Forest Exp. Station Prog. Rept. 2. (Unpublished).

Parmeter, J. R. and R. F. Scharpf. 1972. Spread of dwarf mistletoe from discrete seed sources into young stands of ponderosa and Jeffrey pines. USDA For. Serv. Research Note PSW-269.

Ridley, H. N. 1930. The dispersal of plants throughout the world. Reeve and Co., Kent, England. 744 p.

Roth, I. F. 1953. Dwarf mistletoe on the Pringle Falls Experimental Forest. USDA Pacific NW Forest and Range Exp. Sta. Res. Note 91. 3p.

Scharpf, R. F. 1970. Seed viability, germination and radicle growth of dwarf mistletoe in California. USDA For. Serv. Research Paper PSW-59.

Scharpf, R. F. and J. R. Parmeter. 1971. Seed production and dispersal by dwarf mistletoe in overstory Jeffrey pines in California. USDA For. Serv. Research Note PSW -247 .

Smith, C. C. 1968. The adaptive nature of social organization in the genus of tree squirrels Tamiasciurus. Ecol. Monographs 38:31-63.

Smith, C. C. 1970. The coevolution of pine squirrels (Tamiasciurus) and conifers. Ecol. Monographs $40: 349-371$.

Smith, C. C. 1975. Coevolution of animals and plants. Symposium V, 1st Int. Cong. of Syst. and Evol. Biology (Eds. I. E. Gilbert and P. H. Raven). University of Texas Press, Austin, Texas.

Stewart, J. and K. Shea. 1970. Forest diseases of the pacific northwest. USDA For. Serv.

Wicker, E. F. 1967. Seed destiny as a klendusic factor of infection and its impact upon propagation of Arceuthobium spp. Phytopathology 57:1164-1168.

Zilka, P. J. 1973. Possible avian influences in the distribution of dwarf mistletoe. M. S. Thesis, Portland State University, Portland OR. $43 p$.

Zilka, P. J. and R. O. Tinnin. 1976. Potential avian influence in the distribution of dwarf mistletoe. Northwest Sci. 50:8-15. 